\title{
Confronted by Indigenous Metaphysics in the Academy: Educating against the Tide
}

\author{
Carl Mika \\ Associate Professor, Te Whiringa School of Educational Leadership and \\ Policy, Faculty of Education, University of Waikato, New Zealand \\ mika@waikato.ac.nz
}

\begin{abstract}
Discussions about indigenous philosophy are always difficult because of identities, chief among these being: what is the primary assumption that coalesces the varied philosophies of indigenous groups that then entitles me to talk about a single "indigenous" philosophy? Although I don't make this the focus of my paper, I take as a uniting thought the holism which defines metaphysics for several indigenous groups (see e.g. Deloria, 2001; Mika, 2017; Smith, 2012). For this article, I centre on the implications of indigenous holism for both indigenous and non-indigenous students and the indigenous teacher of metaphysics in the academy. This paper often takes a turn for the anecdotal as I consider my experiences in the New Zealand context as a Maori lecturer in philosophy of education who teaches Maori metaphysics to Maori and non-indigenous students. There are difficulties that exist for me as an educator in this area and also for the students, although I have observed that non-indigenous and Maori students encounter Maori metaphysics in quite unique ways. A common feature in both cases, though, is that there is a lack of appropriate language to draw on to describe Maori metaphysics. I conclude this article by suggesting ways that philosophising can take place in correspondence with a Maori metaphysics of things as world-constituted.
\end{abstract}

\section{Keywords}

indigenous - metaphysics - holism - education - worldview 
Depending on one's viewpoint, indigenous philosophy is at best the poor cousin of dominant western thought in the academy. In its worst conception, it is completely invisible or reduced to something unphilosophical. All this, despite the emergence of a "rhetoric of indigenous knowledges [which] has been heralded as seemingly a way out of the development impasse" (Briggs \& Sharp, 2004, p. 661). In universities, indigenous philosophy often shows itself in the form of ceremony or as a mystical garnish to an empirical explanation but not generally as a credible, theoretical base in its own right, particularly in the formal discipline of philosophy. Its negligibility in that context may have something to do with two aspects: that metaphysics is not prominent in a milieu that tends to encourage more self-evident modes of description; and the fact that indigenous philosophy requires talk of metaphysics and a holistic one at that (Deloria, 2001; Mika, 2017; Smith, 2012). Not only is holism privileged by indigenous thinkers and practitioners but it also opens directly onto a massive, colonial rupture between the indigenous self in an embodied and spiritual sense and dominant western thought. Being a colonial issue that necessarily becomes counter-colonial in indigenous philosophy, there are various skeins of thought that resent indigenous metaphysics of holism and manifest resentfully in the space being considered. The space that I am concerned with here, as an indigenous (Maori) lecturer who teaches both his own philosophies and those of the west, is the university.

This problem and others play out in indigenous philosophising in the academy and make themselves known in the lecture hall. Despite insisting on keeping philosophy at the forefront of this article, I suggest there are certain immediate tendencies observable in the classroom for the indigenous teacher and indigenous and non-indigenous students. These are symptomatic of the challenges that indigenous holism poses for us all in education. The first of these arises through an assumption that concepts will be clear and evident: here, with a Maori worldview, I discuss how, as both indigenous teachers and students, we strive to represent things with the ethics of interconnectedness in mind (Arola, 2011) but find it difficult to do so when the appropriate language is scarce in the academy. Non-Maori students especially, I have observed, initially retreat from the intellectual challenges of indigenous first principles, although many of them remain fascinated by the propositions and attempt to understand them fully, sometimes successfully. But it is their first, instinctive dismay at the realisation we are not discussing terms and concepts in familiar ways that is compelling for this article. With some exceptions, Maori students, on the other hand, typically understand the complexity of their metaphysics 
but do not tend to progress the philosophising that is needed for metaphysical speculation, preferring instead to reiterate Maori terms that, perhaps, encapsulate all that needs to be said. But I continue by suggesting that simply staying with these terms is not sufficient to build up a corpus of Maori metaphysics. Both groups of students, in different ways, encounter huge obstacles when either attempting to understand indigenous metaphysics of holism or articulating and building on the philosophising that has gone before. In all cases, the indigenous metaphysics philosopher has an ethical obligation to present concepts as constituted by the world (and hence holistic) whilst having to deal with the demise of metaphysics as a concern in the academy and having to contend with the difficulties that western metaphysics poses when teaching indigenous first principles.

\section{2 Scenario: A Lecture on Maori Metaphysics}

Lengthy introductions promise much, but then so do indigenous philosophy lecturers. In a recent lecture I delivered to teacher training students on an aspect of Maori philosophy, I was struck more than usual by the difference in categories of things as between Maori and dominant western logic. In the introduction to that lecture in which I elaborated at length on what I was about to discuss, I mentioned the notion of "ground" and how it is viewed in Maori thought. In Maori metaphysics, the ground is related to the Earth Mother, which is a poor translation for a primordial entity that, despite existing outside time (Marsden, 2003), is one entity that structures our everyday existence (Mika, 2017a). It is related to the Sky Father and to that extent forms two of the phenomena of Heidegger's (1971) Fourfold, for instance, but it heralds a characteristic more radically interconnected than his because Earth Mother and Sky Father are in fact completely one. From the discussion that ensued, it appeared the Maori students understood the determinedly holistic thinking (and obscurities) these descriptions involved, but the non-Maori students struggled with the metaphysical concepts. Questions arose as to the labels "sky" and "ground": how can something be a "ground" if it keeps conceptually regressing from us - how can it be a non-foundational ground? How are two and more entities one thing and yet separate at the same time? How can something exist both within and outside of "time" (and indeed what if there is a complete collapse of time at work, as in Maori thought (see eg. Mika, 2017b)). I was reminded of Jones' (2001) observation of anxiety among Pakeha (European) students when non-Western knowledge was put to the centre of thought in the classroom. The basic clarifications that arose from those confusions sit with a thirsty 
appetite for formal logic and are therefore understandable to that extent. The apparent introduction to the lecture, however, quickly became a philosophical discussion of terms and principles of Maori thought and I didn't manage to talk about education before the lecture had to conclude. In some respects, the introduction had become the content, and I discovered that not only was I dealing with students' lack of understanding of the Maori language; I was also challenged by the lack of training in a particular way of thinking in education - a lack we all have to deal with when we're trying to think in terms of "whakaaro" or thought-beyond-the-visible (Mika, 2014).

The search for meaning in indigenous philosophy, in the academy at least, is underscored by a basic skirmish between some fundamental principles of thought, and this mutual distrust of worldviews played out in the lecture. We should also note that the Maori language is not necessarily more adept at protecting Maori metaphysics than English; calculative or rationalistic thought, striven for in the academy, sits at the base of both, directing how they are meant to be used. Undoubtedly, I could have set out to deal with the entire lecture by simply giving Maori terms and their quick definitions through translation, but from there they can become equated with performativity and ceremony, and to my mind this needed to be avoided.

I have found non-Maori (and some Maori) students often want to see Maori philosophy addressed in terms of the pohiri (welcoming ceremony), to give one example. Their tendency to equate philosophy with familiar discourses and thence to ceremony may be due to the fact that, in the New Zealand setting, the pohiri is well-established, marks a very visible difference from nonMaori custom, and yet is frequently carried out in non-Maori settings. In that sense, there may be a comfort in curbing Maori philosophy to keep it familiar. However, when talk of a more theoretical nature is introduced, as I noted, these students' desire for clarity suddenly asserts itself in the form of unease. Here, confusion reigns, because these students have likely not been exposed to a theoretical, non-performative version of Maori philosophy, and indeed they may not have been exposed even to their own abstract philosophies. Suddenly, there may be no mention of the usual Maori definitions they are used to tapu (sacred), noa (profane), mauri (life-force) - and there is now another set of Maori terms - kore (nothingness, despondency, absence), whakapapa (becoming-ground), Ranginui (attunement) - that open up onto thinking within interconnectedness and its offshoot, obscurity. Maori terms, hitherto formalised and hardened to mean a particular practice, become theoretical and maybe even disconnected from ceremony. And students often become out of sorts. 
Importantly, another tendency arises, this time almost exclusively with Maori students. I noticed during discussion that the students reiterated single Maori terms among English ones without explaining their meaning. They were left as implicitly self-explanatory. When they thought more deeply about the terms in relation to a metaphysics that did not privilege the human self or a western rationality and were asked to develop the philosophising, they reluctantly abandoned repeating the term for a discussion in English. It is the reiteration of the terms, as if they are self-sufficient (and sometimes tied up with that anthropocentrism) that I suspect signals a deeper issue. A quick answer to this problem would be simply that Maori students understand well what they mean and don't see the need to further explain. Another might be that, after years of oppression, the Maori language is now a bastion that provides some protection in a situation that calls for a high degree of theorizing (and transcending the ground of existence that we ethically reside in - more on that later) - even if the Maori language is used as self-evident. That latter explanation is closer to the truth, I suspect, and related to it is that there is a lack of language to adequately describe the metaphysics of interconnection in English in plausible ways for the Maori student. It is a problem that confronts the indigenous metaphysics lecturer as much as the student.

For the Maori students, I could have simply accepted the self-referential Maori terms, but if I had I would have been allowing those terms to stay selfevidently unexplored. Furthermore, in relation to all students, there is an attempt at work on my part to get to the depth of things. It is an interesting facet of indigenous philosophy that it both proposes a holistic view about the world (Deloria, 2001; Calderon, 2011; Arola, 2011) and tries to present things holistically (Mika, 2007), through a theoretical lens. Thus, indigenous philosophy as a discipline is not, in the first instance, about the day-to-day practices of a particular indigenous group (see for further discussion Masolo, 2016). Especially when dealing with non-indigenous students, it seems most pressing for the indigenous philosopher, who does not necessarily want to traditionalise philosophy and source it in collectivist or familiar discourses, to demonstrate to those students that there is a depth of thought and subtlety of onto-epistemological categories equivalent to that of the dominant west. This pursuit of complexity does not mean that we are out to convince western students of our philosophical merit but it is in the students' best interests to know that not all indigenous knowledge rests on the usual traditional utterances that they have become familiar with - and, in fact, that while those utterances may provide an initial prompt for philosophical discussion, they will perhaps not crop up again, instead fading away in favour of 
philosophising. And as I have suggested, this mode of intellectual analysis, in which the familiar is simply a means to thinking, can be as unnerving for the indigenous student as for his/her non-indigenous counterpart.

\section{3}

\section{The Demise of Metaphysics and the Need to Talk about it}

Some greater context is called for here. Those of us working in the field of indigenous philosophy education are dealing with the demise of a particular discipline of western thought in the academy, despite the fact that it remains possibly the most important of all disciplines. As indigenous philosophers, I suspect we all experience a dearth of language to convey our ideas with, or a lack of training among our students to deal with the contradictions that indigenous metaphysics conveys. That is, not only is there a clash of worldviews at stake here; there is moreover in the academy a tendency to frame things "ontically" (Heidegger, 1967) and to only encourage the language for that sort of description. Language that attempts to delve into the very ground of thought is not particularly accessible, compared with the language of quick definition, of thought and practice, which is immediately familiar. To take a Maori term as an example, then: "whakapapa" is commonly translated as "genealogy", but it as a deeply metaphysical sense beyond that easy definition and can signal the immersion of the self within the earth whilst not being able to reach a conceptual foundation (Mika, 2015b). The language we call on as academylocated indigenous philosophers is skewed towards another reality altogether and highlights the mismatch between our thinking/teaching and their delivery to the students.

Central to this overall difficulty of philosophizing is the complexity and unruliness of a Maori metaphysics which signals an ethical obligation. This kind of ethicality is one that, as much Indigenous literature acknowledges, turns on presenting the world as comprising interconnected phenomena. Whilst ethics in the academy almost always concerns itself with research, for indigenous peoples the issue pivots on a much broader difference of first principles (see e.g. Cram, 1997; Dei, 2013; Kovach, 2009; Pidgeon, 2016; Smith, 2012). This divergence of worldviews amounts to a philosophical clash between indigenous fundamental thought, which attempts to maintain a thoroughgoing connection between things in the world, and dominant western ones, which - much more tacitly than the indigenous push for the recognition of interconnection - assume that the world is fragmented (Marsden, 2003). For Maori, the ethics of metaphysics represents a continual, not immediately surmountable, challenge, due partly to the fact that in the academy, metaphysics has been 
largely ignored or even incinerated (Hume obviously looms large here). For various reasons, metaphysics is absolutely crucial to an indigenous ethical argument and so it is has never suffered the same fate for our thinking - yet. The teachings of our elders about interconnection are immediately ethicsrelated and so need to be retained. With their narratives, our elders and things in the world not only disturb conventional spaces between disciplines but they also signal there is a connecting materiality that exists behind them and that our propositions about things should themselves be predisposed to that transphenomenal substance. As colonized individuals and communities, a few challenges inevitably arise for us, namely: the role of our specific metaphysics in our considerations; the nature of our metaphysics; and, whether we can represent the world in terms of its strong interconnection in our thinking.

Indigenous metaphysics hence encounters some difficulties from the very outset in the academy. To begin with, it has not been overly privileged, having sometimes been disregarded by more mainstream philosophers. I suspect this lack of understanding evolves from the fact that indigenous philosophy rests on those fundamental principles that cannot be proven. Anecdotally speaking: I have heard of instances where indigenous philosophers have been asked to verify that the world is interconnected, and I was once asked to prove this very proposition when I submitted a paper to a mainstream publication. Alongside it being impossible to prove these sorts of speculations, these examples more egregiously show a recoil from the possibility that non-eurocentric philosophy may well indeed be philosophy (Mika, 2015a), despite its different form and set of concerns. Several indigenous writers have expressed their concern: Ahenakew et al. (2014) observe that "Very rarely Indigenous knowing is represented as invaluable in and of itself. When this happens, representations are often superficial, stereotypical and based on desires for redemption and re- centring of the Western subject" (p. 220), and Wildcat (2005) identified that Deloria, an indigenous philosopher, encountered difficulties in establishing indigenous philosophy as just that. Pihama (2005) speaks about Kaupapa Maori as shouldering a similar backlash: "The historical dominance of Western theorizing is being challenged at a very fundamental level; that is, at the level of relevance to the Indigenous peoples of this land. For many Pakeha academics this challenge is viewed as a threat" (p. 192). In those instances where indigenous philosophers have been asked to prove something unprovable, a similar "Pavlov's dogs" event arises: if I mention indigenous philosophy with first principles completely different to those of its conventional euro-western counterpart, there is sometimes an immediate, almost primal reaction from the other. Fundamentally, in these instances indigenous ways of thinking that draw on metaphysical concerns are not acknowledged. 
Of course, there are several non-indigenous philosophers and other theorists who do not fit this cast, are in fact comrades in Maori thought (for a fuller discussion on this, see Hoskins (2012)) and would suggest that philosophy hasn't moved on. Along with indigenous philosophers, they would remark that the set of anxieties which arose when the west first encountered indigenous peoples (Sardar, Nandy, \& Davies, 1993) also persist in the deepest recesses of many current mainstream philosophers' minds. While we can (and do) laugh these anxieties off as a peculiarity and a vulnerability, however, they signal something quite sinister: they want to consign indigenous philosophy to another space altogether. Relatedly, these anxieties sometimes intend for indigenous philosophy to be performative, a spectacle, most likely a traditional ceremony (Mika, 2017b). At a stretch, indigenous philosophy could be philosophy of a particular kind with its recitation of genealogies or creation stories, but even then it is more likely a quaint story or set of myths - supernatural and unverifiable. In that sense, they become very similar to the language used to describe Maori ceremony in a very reductive way: occupying a performative, socio-anthropologically interesting space.

\subsection{Consequences for the Indigenous Teacher of Metaphysics}

Very little has been recounted on the experiences of the indigenous philosopher working in the mainstream setting, but it is an important topic. Given the political contexts I have just identified, the indigenous philosophy lecturer must be a hugely political creature, even unintentionally. $\mathrm{S} /$ he has to deal with certain visceral expectations from students. But a more pronounced problem arises here for my own teaching and research which links back to the metaphysics of interconnection I propose as fundamental - and here, and for the rest of this section, my statements are speculatively premised on Maori notions of "worldedness" or world-constitution of things. Mika (2017a) has philosophised on the significance of not transcending the mysterious ground of thought and experience that Maori name "Papatuanuku". Papatuanuku, whilst similar to the western "episteme" in suggesting a ground of experience and thought, diverges hugely from that latter term by emphasising that the human self (and all other things) is constituted by that ground, so as to be absolutely inseparable. The danger of transcending that ground is clear in that philosophy; placing oneself above the things being discussed has adverse consequences for the theorising self, the object(s) being discussed, and ultimately the world. While this profoundly interconnected metaphysics may appear to emphasise human thought too much, it is in fact a weakness of the human self that we are considering here. The human self is capable of interfering with deep interconnection but, I aver, is no deeper a participant in it than, say, a rock or mountain. 
Thus, humans have a negative duty or responsibility, in that they must not act unethically through divorcing themselves from the world while representing it. It follows that the indigenous philosophy educator must steer clear of that distancing project whilst teaching.

At this point, one could argue there is absolute merit in keeping away from philosophising, by staying with the familiar meanings of terms. Linking Maori terms with their common practice, after all, seems to retain their immersion within the world, keeping them within the ground that Maori privilege. Philosophising about those terms, on the other hand, would actually be a standingupon-the-ground that episteme, etymologically and pragmatically, strives for (Mika, 2017a). Here, the opposition between the presentation of things, versus their representation, announces itself. Whitt et al. (2001) have identified the affinity of indigenous knowledges with presenting things in the world, rather than simply mentally constructing them. Seen in that light, Maori concepts are protected in their non-theoretical sense as striving towards a collective act of, say, hospitality (through the welcoming ceremony). This form of narrative would have it that the human self is kept among the worlds' things as a learner of Maori concepts in their practical sense.

Yet, a role of the Māori metaphysics philosopher is to understand that any encounter with things in the world holds a particular ethical responsibility: to render those things as beyond-conceptual and hence mysterious. In that act of mystery, it could be that things are retained within the plane of existence that Maori ceremony attempts to protect. By this I don't mean there is no such thing as thought but that, because thought or perception itself is embedded in whakapapa (one meaning: genealogy), then the concept of a thing needs to be put through a process of undoing. Hoskins (2012) identifies in this regard "a need to take seriously the role of theorisation, not merely as a means to certain pragmatic political ends, but as crucial to possibilities for a robust and open scholarship" (p. 88). Her call makes sense politically but what of our metaphysical argument for the non-human - the "ground" that precedes human experience (Mika, 2015b)? A clue lies in her description "open scholarship". In Maori metaphysics, apparently cognitive phenomena such as scholarship are themselves things that are constituted by the world as a whole (Mika, 2017b). Openness must mean here that a thing, such as scholarship, does not impede that constitutive nature of the world. In other words, scholarship can be thought of as a materiality that is, in all respects, a receptacle of all things. Like (according to dominant Western categories) concrete things, intangible ones such as "scholarship", "happy", "confusion" and so on are entities that manifest as worlded. Open scholarship would be that which is incorporated fully into the matter of all things and the humus within which all things are entangled. 
It seems that philosophising, then, must be fully open to the world in order to be part of that world. Maori traditional narrative is familiar with the undermining of banal categories and their subsequent opening-up. In Maori narrative the demi-god Maui, perhaps aware that movement would only come slowly if he didn't act, was particularly fond of the world's openness, spanning the disciplines through slowing the sun's movement, transporting fire to earth, and - finally and unsuccessfully - setting out to kill the Goddess of Death, Hinenuitepō. Cooper (2012), a Maori philosopher, has suggested that "Māui represented challenge to ... knowledge and traditions, and therefore provided a destabilising force that guarded against hegemony, and opened up pathways for change" (p. 64). We need to consider some steps in thought here: Maui not only succeeded in a highly pragmatic act; he also at-once reflected the world-as-real by undoing the dominance of a particular concept - that of "putting up with a state of affairs'. It is in Maui's willingness to simply deal with/to convention that the world was able to turn. His deeply disruptive actions would call for constantly appraising the state of affairs and imposing on it the brute, sometimes unpalatable reality of the world. The Real for Maui was the full world, including its invisible realms and yet, importantly, the interrelationship between all realms, tangible or otherwise. No mean feat, it is a deep connection between metaphysics as a discipline and its real actors, and between humanity and things in their totality, that Maui insists on, although it is his obvious achievements that we tend to most frequently acknowledge.

Even in his eventual failure involving the Goddess of Death, Maui highlights that ethical behaviour should relate to how one posits the world. Much more recently, and from the domain of the published word, other indigenous thinkers have said similar things. From the early 1980 os, Pere had noted that the Maori worldview was a spiritual one, having repercussions for the educational context that is apparently concrete in nature. For her, there is a proper way of seeing a thing in the world that would be instructive for how the individual perceiver would be formed. Speaking from the academic context, Arola (2011) currently also wants us to think of all our representations as at once ontological and ethical and, with that, undo any suggestion - delivered by the academy - that in such-and-such a place sits formal ethics and "over there" is a conceptual representation. Again, the indigenous philosophy educator must step up to a different category of thought and somehow convey that to students.

If indigenous philosophy is made solely about familiar discourses, then thinking atrophies. In that way, those usual ways of speaking - whether they comprise terms or else particular sentence constructions that invoke a strong familiarity for students - do not really exist in the world. Or, if they do, they 
exist as separate phenomena, able to be picked up and acted out or recounted but unchanging and unmalleable, incapable of committing themselves to the ground that they apparently lie within. Conversely, the world's things do not penetrate the discourse. The thought or discourse is isolated - as much as when the rarefied thinker floats above it. Indeed, with the banal entity at the same level of the human self, another, equal danger arises - the horizontal damage of the petrified thing which remains aloof but insists that it is constantly used. Here, the lateral entity is actually cordoned off from the world through that static use but does not allow for the self to think or orient towards the world differently.

Similarly, terms and concepts that have been highly intellectualised and are therefore novel but self-sufficient are inimical to that Maori existential and metaphysical foundation. The conceptual must, to rephrase Novalis (1960), be elevated to become mysterious and also lowered to become concrete once more. For the Maori indigenous philosophy educator, the worldedness of thought relies on individual philosophising that is then built on later either by him/her or by someone else. S/he cannot (and should not) hope to be the ultimate architect of thought. There are several creative possibilities for the student here too, because $\mathrm{s} / \mathrm{h}$ is not now so much the passive recipient of a knowledge base but is able to build on the speculative nature of the propositions. In this process of creation-destruction - where a proposition can even be useful through the tension it provokes - a thought may be incorporated with a particular view of the thinking human self: that $\mathrm{s} /$ he is fundamentally mysterious and obscure, is uncertain, and is hence interconnected with the entity s/he is considering. In acknowledging the constitution of the self by the entity through thought (it should be noted that thought in Maori philosophy is an entity and is equal to all other things (Mika, 2017b)), the self and entity are presented as one. A continuous overturning of that thought ensures that the self likewise retains his/her mystery.

For the non-indigenous students, the overall problem may simply be one of exposure, as I noted towards the beginning. Admittedly they have to contend with a formal logic (Seung-hwan, 2004) that sits beneath their perception and they have to suspend it in favour of much more contradictory, or at least obscure, thinking. Building thought, however, may be a useful way of keeping familiar discourses at arm's length by using them as scaffolds to further speculative thinking. In that limited sense, there is a place for banal thinking, but it has a limited life-span in Maori metaphysics philosophising. In due course, new thought evolves that the student refers back to a holistic metaphysics and s/he can speculate on how that new thought does correspond to holism. This same approach applies for the Maori student, too, who can ensure his/her statements 
about the world are referenced to a state of interconnection. Moreover, for the Maori student for whom whakapapa (genealogy) is an issue, the learning process can be thought of as one of accrual or constitution by the world. The constitution of the self by the world (and vice versa) is mysterious and thus whakapapa takes on a much more enigmatic tone than its reiteration allows.

\section{Conclusion}

Indigenous philosophy branches into various forms that, I suspect, mirror the subcategories of philosophy in the west - existential, analytic, post-structural, metaphysical, epistemological, ethical, and ontological - as scholars' and students' interest in the broad discipline grows. We might be configuring those genera differently to our western counterparts in various ways, but the scholarship evolving tends to fit within them. Indigenous philosophy's diversification in published literature has happened only in the last few decades. There are, however, only a few specialists within each area. It follows, then, that ways of writing from a Maori viewpoint in each category are not well developed. But there may be some benefits to a lack of language for the Maori educator who is aware of the fading of metaphysics generally in the academy but who must deal with that demise and yet give life to Maori metaphysics in particular. Although those of us who work in this area (and there are admittedly few) are to some extent hindered by that kind of language that tries to orient us back towards the banal, we can establish the necessary language and, more importantly, the thinking that Maori metaphysics calls for. In that way, at least, the language of banality both constrains, yet promises much for, the future of Maori metaphysics in the academy.

\section{References}

Ahenakew, C., Andreotti, V., Cooper, G., \& Hireme, H. (2014). Beyond epistemic provincialism: De-provincializing indigenous resistance. AlterNative, 10(3), 216-231.

Arola, A. (2011). Native American Philosophy. In W. Edelglass \& J. Garfield (Eds.), The Oxford Handbook of World Philosophy (pp. 562-573). New York, NY: Oxford University Press.

Briggs, J., \& Sharp, J. (2004). Indigenous knowledges and development: A postcolonial caution. Third World Quarterly, 25(4), 661-676.

Calderon, D. (2008). Indigenous metaphysics: Challenging Western knowledge organization in social studies curriculum. (Unpublished doctoral dissertation, The University of California, Los Angeles). 
Cooper, G. (2012). Kaupapa Māori research: Epistemic wilderness as freedom? New Zealand Journal of Education Studies, 47(2), 64-73.

Cram, F. (1997). Developing partnerships in research: Pakeha researchers and Maori research. SITES, 35, 44-63.

Dei, G. (2013). Critical perspectives on indigenous research. Socialist Studies, 9(1), 27-38.

Deloria Jr, V. (2001). American Indian metaphysics. In V. Deloria Jr \& D. Wildcat (Eds.), Power and place: Indian education in America (pp. 1-6). Golden, CO: Fulcrum Resources.

Heidegger, M. (1967). Being and time (J. Macquarrie \& E. Robinson, Trans.). Oxford, England: Basil Blackwell.

Heidegger, M. (1971). Poetry, language, thought (A. Hofstadter, Trans.). New York, NY: Perennial Classics.

Hoskins, T. (2012). A fine risk: Ethics in Kaupapa Māori politics. New Zealand Journal of Educational Studies, 47(2), 85-99.

Jones, A. (2001). Cross-cultural pedagogy and a passion for ignorance. Feminism and Psychology, 11, 279-292.

Kovach, M. (2009). Indigenous methodologies: Characteristics, conversations, and contexts. London, England: University of Toronto Press.

Marsden, M. (2003). The woven universe: Selected writings of Rev. Māori Marsden. Otaki, New Zealand: Estate of Rev. Māori Marsden.

Masolo, D. (2016). African Sage Philosophy. Retrieved from The Stanford Encyclopedia of Philosophy: https://plato.stanford.edu/archives/spr2016/entries/africansage/.

Mika, C. (2007). The utterance, the body and the law: Seeking an approach to concretizing the sacredness of Maori language. SITES, 4(2), 181-205.

Mika, C. (2014). The enowning of thought and whakapapa: Heidegger's fourfold. Review of Contemporary Philosophy, 13, 48-6o.

Mika, C. (2015a). Counter-colonial and philosophical claims: An indigenous observation of Western philosophy. Educational Philosophy and Theory, 47(11), $1136-1142$.

Mika, C. (2015b). Thereness: Implications of Heidegger's 'presence' for Maori. Alter Native, 11(1), 3-13.

Mika, C. (2017a). A term's irruption and a possibility for response: A Māori glance at 'epistemology'. In E. McKinley \& L. Smith (Eds.), Handbook of Indigenous Education (pp. 1-19). Dordrecht, Netherlands: Springer.

Mika, C. (2017b). Indigenous education and the metaphysics of presence: A worlded philosophy. Oxon, England: Routledge.

Novalis. (1960). Vorarbeiten zu verschiedenen Fragmentsammlungen. In P. Kluckhohn \& R. Samuel (Eds.), Schriften: Das philosophische Werk I (Vol. 2, pp. 507-651). Stuttgart, Deutschland: W. Kohlhammer. 
Pidgeon, M. (2016). More than a checklist: Meaningful indigenous inclusion in higher education. Social Inclusion, 4(1), 77-91.

Pihama, L. (2005). Asserting indigenous theories of change. In J. Barker (Ed.), Sovereignty matters: Locations of contestation and possibility in indigenous struggles for self-determination (pp. 191-209). Lincoln, NE: University of Nebraska Press.

Sardar, Z., Nandy, A., \& Davies, M. (1993). Barbaric others: A manifesto on Western racism. Colorado, CO: Pluto Press.

Seung-hwan, L. (2004). A typography of Confucian discourse: Politico-philosophical reflections on Confucian discourse since modernity (J. Song \& L. Seung-hwan, Trans.). Paramus, NJ: Homa \& Sekey.

Smith, L. (2012). Decolonizing methodologies: Research and indigenous peoples. London, England: Zed Books.

Whitt, L., Roberts, M., Norman, W., \& Grieves, V. (2001). Belonging to land: Indigenous knowledge systems and the natural world. Oklahoma City University Law Review, 26, 701-743.

Wildcat, D. (2005). Indigenizing the Future: Why We Must Think Spatially in the Twenty-First Century. American Studies 3(4), 417-40. 